\title{
DEPRESSION IN MASTECTOMIZED WOMEN: A BRIEF REPORT
}

\section{Silva CCMS}

Graduating in Medicine at the Federal University of Cariri; 284 Divino Salvador Street, Alto do Rosário, Barbalha, Ceará, Brazil; carlos.silva@aluno.ufca.edu.br; https://orcid. org/0000-0002-8298-4917

\section{Ferreira GM}

Graduating in Medicine at the Federal University of Cariri; giovannigamf@gmail.com; https://orcid.org/0000-0001-7644-3017

\section{Maia EC}

Graduating in Medicine at the Federal University of Cariri; eron_castro@hotmail.com; https://orcid.org/0000-0003-1662-2800

\section{Oliveira LM}

Graduated in Letters at the Regional University of Cariri; leonardomessias40@yahoo. com.br; https://orcid.org/0000-0002-8324-8866

\section{Carmo HMF}

Graduated in Psychology at the Leão Sampaio University Center; hanna.ferreira@outlook. com.br; https://orcid.org/0000-0003-2961-6514

Abstract: Only in the year 2018, over two million cases of breast cancer worldwide have been reported, often treated through mastectomy, showing the importance of the study of this procedure, in relation to the physical, psychological and spiritual sequelae of the patients. The objective was to evaluate how these sequels favor the development of postsurgery depression. A bibliometric research was developed in the Portal of Periodicals of the Coordination for the Improvement of Higher Education Personnel, using the following key words ["mastectomized women" and "depression"] 32 articles found. The results were submitted to the "peer-reviewed journals" filter and "Articles in English and Portuguese", resulting in 10 selected articles that were then merged compiled with information collected from the official WHO and INCA websites to compose this work. Mastectomy aesthetically affects an important component of assertion of womanliness, sexuality and womanhood, post-surgical depression is a common reaction in these patients. Part of these consequences are of a sexual, affective, social and even altered bodily perception. The importance of family, social and professional support in the rehabilitation of these 
women is also emphasized. The review of these articles allowed us to verify the need to analyze the reconstruction of the breast in mastectomized women as a matter of mental health, and not only as an aesthetic desire for them.

Keywords: Mastectomized Womem. Cancer. Depression.

\section{INTRODUCTION}

According to WHO (World Health Organization) only in 2018, they were already notified more than two million cases of breast cancer globally. In which, according to the INCA (National Institute of Cancer José Alencar Gomes da Silva) 59.700 were notified in Brazil.2

Its treatment can be developed over chemotherapy, radiotherapy and also by surgical intervention. This intervention may occur by conservative and less drastic surgeries as lumpectomy, or with the mamma's total evacuation by the mastectomy. However, often, when cancer is discovery in advanced apprenticeships, It is necessary the accomplishment of a mastectomy, resulting in sequels physics, psychological and spiritual in the patient. ${ }^{3}$ Standing out a deep change in the self-worth, in the coexistence, in the socialization and in the own desire to live of the patient post-surgery. ${ }^{4}$

This work is an amendment of published articles about psychological sequels and the current problems of the mastectomy. The objective was to evaluate how the sequels favor the development of a depression picture in the post-surgical period.

\section{MATERIAL AND METHODS}

On December 15, 2018 it was accomplished a bibliometric research to measure the contribution of the scientific knowledge, derived of the publications on the theme exposed in this article. To get into the results, we accomplished our research in the Portal of Newspapers of the Coordination of Improvement of Personnel of Superior Level (CASTRATE - Brazil). In our research, we used the following keywords, in Portuguese; ["mastectomized women" and "depression"]. The results of this research chosen as references for our work created a hole between the referenced publications extending from January 2004 to December 2018. To complete, a consultation of static data was accomplished remain the cases of breast cancer on the WOH (World Organization of the 
Health) web sites and INCA (National Institute of Cancer José Alencar Gomes of Silva) to be compiled with the results of our bibliometric study in the News Portal of CAPES. All shown in Figure 1.

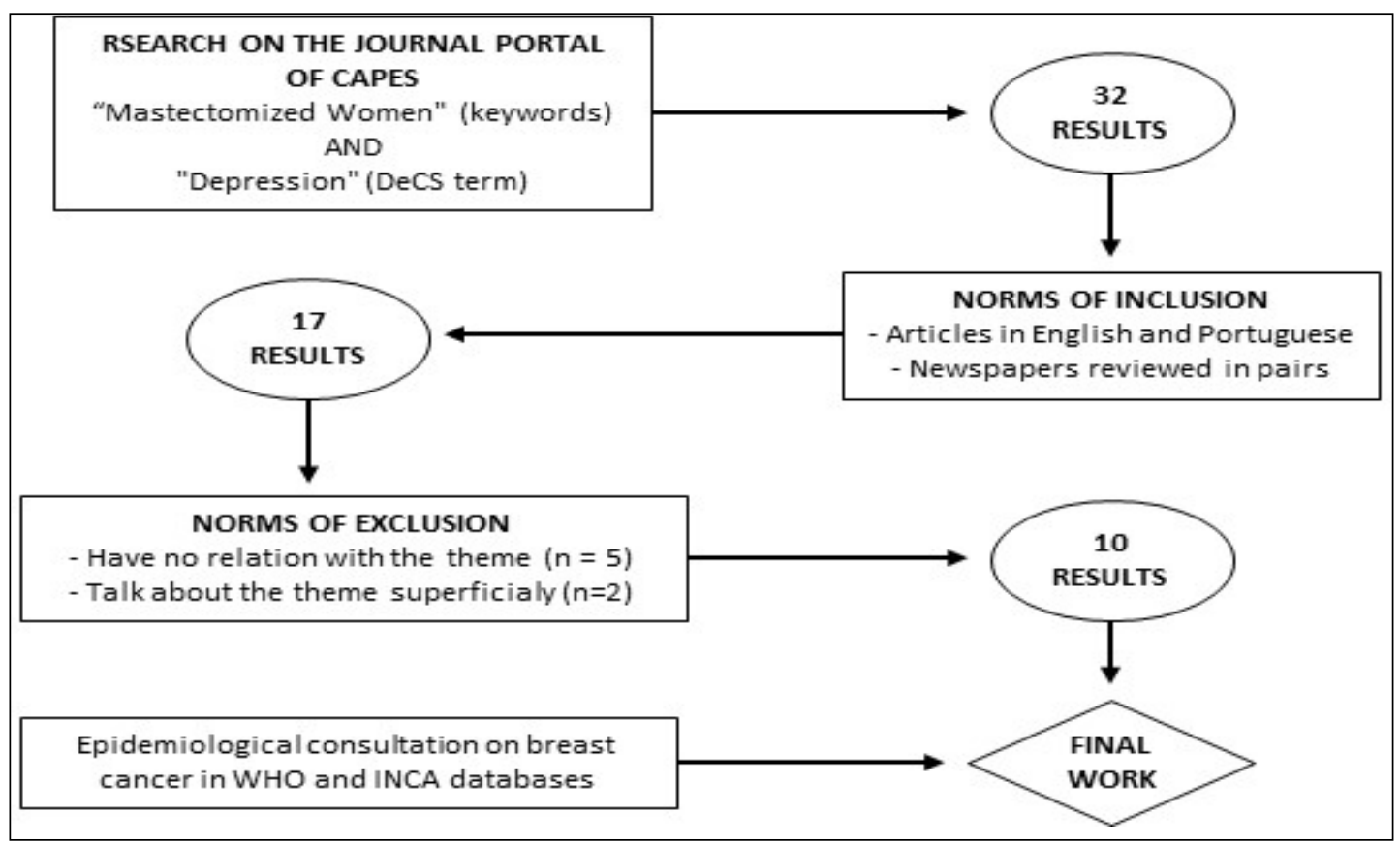

Figure 1 - Flowchart showing the selection of the study for this work. Abbreviations: CAPES: Coordination of Improvement of Personnel of Superior Level; DeCS: Health Sciences Descriptors; OMS: World Health Organization: INCA: National Institute of Cancer.

\section{RESULTS}

Were found 32 articles on the subject. After submitting the search of "Peer reviewed journals" we had kept 17 articles. 5 were excluded because they were not directly related to the theme and 2 were excluded because they were tangent to the theme, remaining 10 articles which were read completely to compose the present work.

\begin{tabular}{|c|c|c|c|}
\hline Authors & Journal & Title & Goal \\
\hline $\begin{array}{l}\text { Fernandes AFC, } \\
\text { Rodrigues MSP, } \\
\text { Cavalcant PP } \\
(2004)\end{array}$ & Rev Bras Enferm. & $\begin{array}{l}\text { Behavior of mastectomized } \\
\text { women face of group activities }\end{array}$ & $\begin{array}{l}\text { To describe women's reactions } \\
\text { to mastectomy and feelings } \\
\text { emerged from group interaction. }\end{array}$ \\
\hline
\end{tabular}




\begin{tabular}{|c|c|c|c|}
\hline Authors & Journal & Title & Goal \\
\hline $\begin{array}{l}\text { Santos DB, } \\
\text { Vieira EM (2011) }\end{array}$ & Ciên Saúde Colet. & $\begin{array}{l}\text { Body image of women with } \\
\text { breast cancer: a systematic } \\
\text { review of the subject }\end{array}$ & $\begin{array}{l}\text { Understanding the relationship } \\
\text { that breast cancer and its } \\
\text { treatments have in the process } \\
\text { of (re)elaboration of women's } \\
\text { body image, aiming to foster } \\
\text { subsidies for the training } \\
\text { and qualification of health } \\
\text { professionals more attentive } \\
\text { to the elevation of their quality } \\
\text { of life. }\end{array}$ \\
\hline $\begin{array}{l}\text { Panobianco } \\
\text { MS, Magalhães } \\
\text { PAP, Soares } \\
\text { CR, Sampaio } \\
\text { BAL, Almeida } \\
\text { AM, Gozzo TO } \\
\text { (2012) }\end{array}$ & $\begin{array}{l}\text { Rev Eletrônica } \\
\text { Enferm. }\end{array}$ & $\begin{array}{l}\text { Prevalence of depression and } \\
\text { fatigue in a group of women } \\
\text { with breast cancer }\end{array}$ & $\begin{array}{l}\text { The objective of this cross- } \\
\text { sectional study was to identify } \\
\text { and evaluate the occurrence } \\
\text { of symptoms of depression } \\
\text { and fatigue in women } \\
\text { undergoing radiotherapy and/o } \\
\text { chemotherapy for breast cancer } \\
\text { for one year or less. }\end{array}$ \\
\hline $\begin{array}{l}\text { Peres RS, } \\
\text { Santos MA } \\
(2009)\end{array}$ & $\begin{array}{l}\text { Psicol Teor e } \\
\text { Pesqui. }\end{array}$ & $\begin{array}{l}\text { Personality and Breast Cancer: } \\
\text { Scientific Production in Psycho- } \\
\text { Oncology }\end{array}$ & $\begin{array}{l}\text { Accept a systematic review } \\
\text { of the scientific literature } \\
\text { devoted specifically to the role } \\
\text { of personality in the evolution } \\
\text { of the clinical and emotional } \\
\text { condition of women with breast } \\
\text { cancer. }\end{array}$ \\
\hline $\begin{array}{l}\text { Majewski JM, } \\
\text { Lopes ADF, } \\
\text { Davoglio T, } \\
\text { Leite JCC (2012) }\end{array}$ & Ciên Saúde Colet. & $\begin{array}{l}\text { Quality of life of women } \\
\text { recovering from breast cancer } \\
\text { after being subjected to } \\
\text { mastectomies compared with } \\
\text { those } \\
\text { who had conservative surgery: } \\
\text { a review of the literature }\end{array}$ & $\begin{array}{l}\text { This study reviews the literature } \\
\text { on the quality of life (QoL) of } \\
\text { women with breast cancer } \\
\text { who have been subjected to } \\
\text { mastectomy, compared with } \\
\text { those who had conservative } \\
\text { surgery. }\end{array}$ \\
\hline $\begin{array}{l}\text { Cesnik VM, } \\
\text { Santos MA } \\
(2012)\end{array}$ & $\begin{array}{l}\text { Psicol Reflexão e } \\
\text { Crítica }\end{array}$ & $\begin{array}{l}\text { Mastectomy and sexuality: an } \\
\text { integrative review }\end{array}$ & $\begin{array}{l}\text { This study aimed to investigate } \\
\text { the impact of breast cancer } \\
\text { and mastectomy in women's } \\
\text { sexuality through the analysis } \\
\text { of scientific literature published } \\
\text { from } 2000 \text { to } 2009 \text {. }\end{array}$ \\
\hline $\begin{array}{l}\text { Simeão SFAP, } \\
\text { Landro ICR, } \\
\text { Conti MHS, } \\
\text { Gatti MAN, } \\
\text { Delgallo WD, } \\
\text { Vitta A (2013) }\end{array}$ & Ciên Saúde Colet. & $\begin{array}{l}\text { Quality of life of groups of } \\
\text { women who suffer of breast } \\
\text { cancer }\end{array}$ & $\begin{array}{l}\text { This study sought to investigate } \\
\text { the quality of life of women } \\
\text { who suffer from breast cancer } \\
\text { and are part of a support group, } \\
\text { comparing the data gathered } \\
\text { from mastectomized women } \\
\text { who had breast reconstruction } \\
\text { and women who had not } \\
\text { had surgery. It also compared } \\
\text { data of women who had } \\
\text { quadrantectomy surgery but } \\
\text { did not need reconstruction } \\
\text { and those who had not had } \\
\text { reconstruction surgery. }\end{array}$ \\
\hline
\end{tabular}




\begin{tabular}{|c|c|c|c|}
\hline Authors & Journal & Title & Goal \\
\hline $\begin{array}{l}\text { Canicali Primo } \\
\text { C, Amorim } \\
\text { MHC, Castro } \\
\text { DS, Paraguassú } \\
\text { TC, Nogueira TP, } \\
\text { Bertolani GBM } \\
\text { (2013) }\end{array}$ & $\begin{array}{l}\text { Investig y Educ en } \\
\text { Enfermería }\end{array}$ & $\begin{array}{l}\text { Stress in mastectomized } \\
\text { women }\end{array}$ & $\begin{array}{l}\text { To evaluate the stress level } \\
\text { in women who have had } \\
\text { mastectomy and analyze the } \\
\text { relationship between stress and } \\
\text { sociodemographic, clinical, and } \\
\text { social support variables. }\end{array}$ \\
\hline $\begin{array}{l}\text { Tavares JSC } \\
(2009)\end{array}$ & $\begin{array}{l}\text { Interface - } \\
\text { Comun Saúde, } \\
\text { Educ. }\end{array}$ & $\begin{array}{l}\text { Families of women which suffer } \\
\text { with breast cancer: challenges } \\
\text { associated with care and coping } \\
\text { factors }\end{array}$ & $\begin{array}{l}\text { Describe and analyze the main } \\
\text { repercussions of breast cancer } \\
\text { and its treatment, reported } \\
\text { by patients and their families, } \\
\text { identifying the factors that } \\
\text { stood out in the process of } \\
\text { dealing with this disease. }\end{array}$ \\
\hline $\begin{array}{l}\text { Fonseca S, } \\
\text { Lencastre L, } \\
\text { Guerra M (2014) }\end{array}$ & $\begin{array}{l}\text { Paid (Ribeirão } \\
\text { Preto) }\end{array}$ & $\begin{array}{l}\text { Life satisfaction in women with } \\
\text { breast cancer }\end{array}$ & $\begin{array}{l}\text { This study aimed to analyze } \\
\text { the relationship between } \\
\text { satisfaction with life, sense of } \\
\text { life, optimism, body image and } \\
\text { depression in } 55 \text { women with } \\
\text { breast cancer, organized into } \\
\text { two groups: mastectomized and } \\
\text { tumorectomized. }\end{array}$ \\
\hline
\end{tabular}

Figure 2 - Guiding Studies and their objectives

The very nature of cancer, with peaks and troughs, uncertainty about the future, the possibility of recurrence and death creates periods of depression, ${ }^{3}$ which can be noticed, most notably in cases of women with breast cancer submitted to the mastectomization, in which studies are categorical in reporting that post-surgical depression is a common reaction, reaching almost half of the mastectomized women. ${ }^{3,5}$ In part, depression branches from the fact that mastectomy is a traumatic surgery, since it aesthetically affects an important component of affirmation of femininity, sexuality and the motherhood of women, ${ }^{6}$ so that patients who have undergone less radical interventions, such as conservative surgery, or those who have undergone surgery to the mastectomy, usually due to the advanced stage of the neoplasia, but who underwent reconstructive surgery reported better quality of life guided as a result of the improvement in self-esteem that is given back to them from the moment in which these women regain their femininity and sensuality regained, as the research had proved. ${ }^{7}$

Therefore, researches had also indicated that mastectomized patients had several symptoms that contribute to the degrading of their healthy sexual lives, since studies emphasize the loss of breast as a traumatic event that buries sexuality, femininity supporting to the worsening of the isolation and depression, reporting, in $24 \%$ of articles, 
psychological stress as a result of worsening sexual life. ${ }^{8}$ This is a result of physiological problems such as decreased vaginal lubrication and excitement, fewer sexual desires, dyspareunia, and anorgasmia ${ }^{4}$ besides more subjective factors, such as a negative change in their own body perception, which leads them to feel less attractive to their partners, leading to an exponential process of decreasing frequency and satisfaction of sexual interaction, and avoidance of social situations, such as going to the beach, clubs and even using sensual clothes. ${ }^{4}$

Improvements were observed in patients who underwent breast reconstruction, which allowed for a lower social isolation, as occurred outstanding to the fear of nonacceptance in the groups, showing breast reconstruction as a health promoting factor, restoring femininity, self-esteem and improving eminence of life of the patients, ${ }^{9}$ improvements in the quality of life were also observed in women who participated in psychosexual couples' therapies and in those who did not have a secure partner, ${ }^{4}$ probably due to self-collection being lower in these women.

Specialized support groups employ a strong positive influence in minimizing the deleterious effects of mastectomization as well as in reassessment of feelings in these women, providing a better rehabilitation and a significant improvement of those women who participated in specialized support groups. ${ }^{3}$

\section{DISCUSSION}

The finding of breast cancer changes a woman's life, and represents an emotional overload, which can cause affective-emotional imbalances such as depression, anxiety or even psychosis, as well as acts as a stress-generating event for some patients. ${ }^{10}$ The complexity of the study of breast cancer is partly due to changes in women's lives, modifying the roles that contribute to identity formation, future expectations, appearance and real functioning of the body. ${ }^{11}$ In this situation, women experience an important process of body image reformulation. ${ }^{4}$ During this process, stress along with factors of genetic predisposition contributes to generate a continuing vulnerability to depression and anxiety disorders. ${ }^{10}$

The extraction of the breast is a surgical process considered violent, since it is followed by consequences, often traumatizing, in the experiences of life, and by affecting 
the health of the woman affected by cancer. ${ }^{3}$ Mastectomized women tend to develop more depression than women with lumpectomy. ${ }^{11}$ In the first few years following mastectomy, depression is usually a common reaction. ${ }^{3}$ Chemotherapy can lead to alopecia, amenorrhea, and mouth ulcers, and others that affect women's sense of identity even more."

Breast cancer focuses on the main corporeal symbol of femininity, sensuality, sexuality and motherhood. ${ }^{6}$ Breast reconstruction returns the femininity, enhances selfimage and sexual life, permitting these women to exhibit positive and satisfying attitudes with the body, recovering its quality of life. ${ }^{9}$

After the extraction of the breast, sexual performance is compromised, with a reduction in the frequency of sexual action in the early stages of treatment and decreased pleasure, interest and sexual satisfaction. ${ }^{8}$ In addition, husbands reported difficulty in caring for their wives because of their aggressiveness, especially when they encouraged compliance with medical recommendations and when they tried to "encourage" them to evade depression. ${ }^{12}$ Therefore, self-help groups are considered important mechanisms in the process of rehabilitation of the mastectomized women, as well as, for example, in her acceptance of cancer and the condition of a woman who underwent a mastectomy. Assistance to women with mastectomies should encompass a broad context involving the cultural, educational, economic and social aspects of each one of them. ${ }^{3}$

\section{CONCLUSION}

The review of these articles published and annexed in the CAPES journal base allowed us to analyze the consequences of and hostile and radical treatment, but often the most effective solution, which is mastectomy. And as in a post-surgical period, the mutilation of the patient's body, one of her main feminine symbols that are her breasts, results in a picture that falls short of the physical sequels: sadness, suicidal ideation and low self-esteem, ending with development of depression among these women.

It was noticed that besides the fear of death, faced by a possibility of relapse of the disease after the surgery, there are many variables that affect patients as well as their relatives. Fear of non-acceptance by society results in isolation, preventing these women from leaving as often as they did before surgery. Meanwhile, their sexual relations, especially those with a constant partner, have been reduced, then, there is a fear that 
they will not be more "wanted" in the eyes of their partners, since for them the breasts characterized them as woman and mother, and, in the absence of it, would have lost that symbol, consequently, they feel less attractive, less women.

The articles evaluated showed that the post-surgical period is very hard, especially in those who did not perform surgical procedures more conservative and failed to perform breast reconstruction after mastectomy. However, the patients gradually managed to participate in groups that support mastectomized women, clarify doubts, reduce social isolation and optimize rehabilitation, essential points to reduce the risk of depression.

At the end of this analysis, it was possible to verify the need for further studies on the theme, promoting a broader post-surgical view in women who underwent a mastectomy, focusing mainly on psychological aspects, addressing the perspective of depression, as well as their relationships with family members. Besides the need to analyze the reconstruction of the breast in mastectomized women as a matter of mental health, and not only as a mere aesthetic desire for them, because, in addition to the cure of cancer, one must avoid the consequences of it, as a main point, depression associated with their mastectomy treatment.

\section{CONFLICTS OF INTERESTS}

The authors of this article affirm that there are no conflicts of interests here.

\section{REFERENCES}

1. Organização Mundial da Saúde. Folha informativa - Câncer. 2018. Available from: https://www.paho.org/bra.../index.php?option=com_content\&view=article\&id=5 588: folha-informativa-cancer\&ltemid=839

2. Instituto Nacional do Câncer. Estimativa de novos casos [Internet]. 2018. Available from: http://www2.inca.gov.br/wps/wcm/connect/tiposdecancer/site/home/ mama

3. Fernandes AFC, Rodrigues MSP, Cavalcant PP. Comportamento da mulher mastectomizada frente às atividades grupais. Rev Bras Enferm. 2004;57(1):31-4 . 
4. Santos DB, Vieira EM. Imagem corporal de mulheres com câncer de mama: uma revisão sistemática da literatura. Ciên Saúde Colet. 2011;16(5):2511-22.

5. Panobianco MS, Magalhães PAP de, Soares CR, Sampaio BAL, Almeida AM, Gozzo TO. Prevalência de depressão e fadiga em um grupo de mulheres com câncer de mama. Rev Eletrônica Enferm. 2012;14(3):532-40.

6. Peres RS, Santos MA. Personalidade e Câncer de Mama: produção Científica em Psico-Oncologia. Psicol Teor e Pesqui. 2009;25:611-20.

7. Majewski JM, Lopes ADF, Davoglio T, Leite JCC. Qualidade de vida em mulheres submetidas à mastectomia comparada com aquelas que se submeteram à cirurgia conservadora: uma revisão de literatura. Ciên Saúde Colet. 2012;17(3):707-16.

8. Cesnik VM, Santos MA. Mastectomia e Sexualidade: uma Revisão Integrativa. Psicol Reflexão e Crítica. 2012;25(2):339-49.

9. Simeão SFAP, Landro ICR, Conti MHS, Gatti MAN, Delgallo WD, Vitta A. Qualidade de vida em grupos de mulheres acometidas de câncer de mama. Ciên Saúde Colet. 2013;18(3):779-88.

10.Primo Canicali C, Amorim MHC, Castro DS, Paraguassú TC, Nogueira TP, Bertolani GBM. Estresse em mulheres mastectomizadas. Investig y Educ em Enfermería. 2013;31.

11. Fonseca S, Lencastre L, Guerra M. Satisfação de vida em mulheres com câncer de mama. Paid (Ribeirão Preto). 2014;24.

12. Tavares JSC. Famílias de mulheres com câncer de mama: desafios associados com o cuidado e os fatores de enfrentamento. Bomfim LA, tradutora. Interface - Comun Saúde, Educ. 2009;13:395-408.

Recebido em: 18 de abril de 2019 Avaliado em: 30 de julho de 2019 (Avaliador A) Avaliado em: 2 de agosto de 2019 (Avaliador B) Aceito em: 20 de agosto de 2019 
